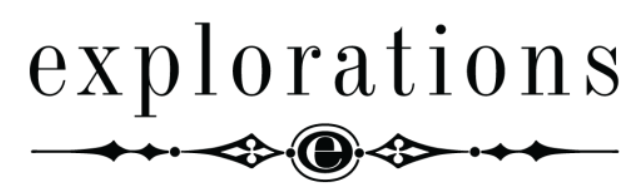

Explorations: A Journal of Language and Literature

\title{
Equivalence Revisited: Polish Perspectives on the Topic
}

DOI: $10.25167 / \mathrm{EXP} 13.19 .7 .1$

\author{
Pawet Marcinkiewicz (University of Opole) \\ ORCID: 0000-0002-7086-1805
}

Why concern ourselves with the old-fashioned concept of "equivalence"? Why now, when Translation Studies has been so swift to adopt the tools offered by postmodern methodologies and has apparently abandoned the clumsy grand narratives of its past, such as "fidelity" or "translatability"? And why should "Polish perspectives" be more interesting and inspiring than any other? In their "Introduction" to Constructing Cultures: Essays on Literary Translation, Susan Bassnett and André Lefevere try to recount a history of Translation Studies, which was still very brief, back in 1998. ${ }^{1}$ In the 1970s, the agenda behind the analyses of translatability was the development of machines which would make perfect translations. The notion of machine-like excellence implied that translation could and should be "good," always and everywhere. According to Bassnett and Lefevere, the end of the 1970s was exactly the moment when the totalizing ideal of machine translation crumbled and what followed was "the long retreat and final disintegration of the once key concept of equivalence" $(1998,1)$.

Yet, the idea of equivalence has survived, albeit in a less abstract, universally strict form: contemporary translators might decide for a specific degree of equivalence that could be pragmatically applied within a concrete text. Moreover, without the concept of equivalence, the idea of translation itself would become problematic: reformulating a source text written in a certain code requires the translator to operate on at least two grids - the cultural and the textual - which are related, and we need equivalence to measure

\footnotetext{
${ }^{1}$ In his "Foreword" to the same book, which is a subtle in memoriam devoted to Lefevere who passed away prematurely in 1996, Edwin Genzler recounts the impressive scientific output of both scholars, but particularly André Lefevere, who in 1992 alone published three books on translation: Translation, Rewriting, and the Manipulation of Literary Fame, Translation/ History/ Culture: A Sourcebook, and Translating Literature (Genzler 1998, xi).
}

Explorations: A Journal of Language and Literature, 7 (2019), pp. 2-6 
their relationship in order to navigate the very activity of translation. ${ }^{2}$ A focus on Polish perspectives on equivalence may be interesting for several reasons: the Polish book market still strongly depends on translation, although to a lesser extent than a decade ago. ${ }^{3}$ Moreover, Translation Studies has become an extremely popular discipline among Polish students and scholars, offered on graduate and postgraduate programs at universities and other educational institutions. ${ }^{4}$ And last but not least, translation has started to emerge as an important topic in public debates on contemporary Polish culture, triggered by writers, translators, and university professors. ${ }^{5}$

Taking into consideration all of the above, when I received a proposal to work as a guest editor of a special issue of Explorations, I knew immediately that it had to be focused on translation. I asked colleagues specializing in different aspects of translation theory and practice - mostly literary translations, but also translation teaching methodology and lexicography - to contribute papers on important aspects of Translation Studies from the perspective of their own research. To my surprise, most - if not all papers touched on the problem of equivalence. From the broadest perspective, the history of equivalence is central to the history of translation itself, with its dichotomy of two major approaches, which Bassnett and Lefevere label as the "Jerome Model" and the "Horace Model" (Bassnett and Lefevere 1998, 2-7). Saint Jerome (331-420 AD), with his translation of the Vulgate, set the standards for translation in the West for the next few hundred years, privileging the translator's fidelity to the original text, but never explaining how "faithful" he or she should be. For Horace, fidus interpres was faithful to his clients and a good translation was a result of a successful negotiation between two parties - and two languages - which might well neglect the letter of the original text (Bassnett and Lefevere 1998, 2-7). Almost fifteen centuries later, in his essay "On the Different Ways of Translating," Friedrich Schleieremacher extends the above models with a call for the standardization of translation procedures, which in fact privileges the foreignizing technique: translations from different languages into German should read and sound different, and the reader should be able to recognize the source language of translation (Bassnett and Lefevere 1998, 2-7).

The above tentative history of equivalence was first narrated by scholars associated with the cultural turn in Translation Studies: Susan Bassnett, André Lefevere, and Lawrence Venuti. Yet, in the $20^{\text {th }}$ century, Eugine Nida was the first academic who systematized loose intuitions on the relationship between the translation and the original. In his seminal Towards a Science of Translating (1964), Nida develops the concepts of

\footnotetext{
2 In his "Composing the Other," Lefevere distinguishes between the "conceptual grid" and the "textual grid," which are intertwined in all linguistic codes, resulting from the "socialization process" (Lefevere 1999, 75-76).

3 According to a 2017 survey by Biblioteka Naradowa (Polish National Library), translations constitute 21 percent of the book market in Poland, the same amount as in France (https://www.bn.org.pl/download/document/ 1564138112.pdf). In 2011, translations constituted as much as 49 percent of the book market, which was the highest amount in Europe (https://www.bn.org.pl/download/document/1342181669.pdf).

${ }^{4}$ Translation specialization can be found on the curricula of all Polish academic universities and universities of applied sciences.

${ }^{5}$ For example, when Olga Tokarczuk won the Man Booker International Prize for her novel Bieguni in the English translation by Jennifer Croft in May 2018, translation-related topics were often discussed in the Polish media. And in 2019, Prof. Jerzy Jarniewicz's book of essays on translation Ttumacz między innymi [The Translator among Others] was shortlisted for one of the most prestigious Polish literary awards, the Nike Literary Award.
} 
Roman Jakobson, who claimed that - although some vowels had symbolic values - each language was a separate code and, therefore, no full equivalence existed (Nida 1964, 31). On the other hand, Nida stresses the importance of a measurable relationship between the translation and the source text, and his idea of "correspondence" is intentionally much broader than that of his contemporaries, such as Max Beerbohm and J.B. Philips, or predecessors, such as F.W. Newman and Matthew Arnold. ${ }^{6}$

For Nida, the most intriguing aspect of correspondence is the dissonance unavoidably introduced into the translation by the clash of the "content" and the "form," excluding a possibility of a "happy compromise" between the meaning and the style (Nida 1964, 164). Nida's revolutionary solution to the above problem was to allow the translator to choose between two different types of correspondences, the first of which was termed the "formal equivalence" and the second the "dynamic equivalence." The formal equivalence was supposed to reproduce such features of the text as grammatical structures, meaning consistence, and sentence/ paragraph/ verse division. However, the dynamic equivalence aimed at creating an "equivalence of response" in the reader, by "co-suitability of the text" based on "naturalness of expression" (Nida 1964, 168). In Nida's opinion, the choice of those strategies depends on the translator, and the American scholar never claims that the strategies exclude each other and cannot be used simultaneously, in a translation of a single text.

Other mid- $20^{\text {th }}$ century translation theorists, following in Nida's footsteps, tried to grasp precisely what equivalence meant in terms of linguistic and semantic changes. In 1958, Jean-Paul Viney and Jean Darbelnet defined equivalence as a technique of using procedures - i.e. concrete translation methods - by which the translation tried to follow the original. Those methods include borrowings, calques, literal translations, transpositions, modulations, adaptations, and equivalence, all of which measure the distance between the original and the translation (Lee 2018, 20-23). Independently from the above mentioned theories, in 1964 the Scottish linguist John Catford defined equivalence as a series of shifts, among which we can distinguish level shifts and category shifts, divided into structure shifts, class shifts, union shifts, and intra-system shifts (Lee 2018, 20). Thus, equivalence became a model for a successful translation, yet a model that was impossible to follow, as it was unavoidably distorted by the particulars of a concrete translation task.

In the $20^{\text {th }}$ century, the history of literary translations from English into Polish is a slow departure from the formal equivalence based on syntagmatic translation, which borrows structures and uses the first dictionary equivalents, towards the dynamic equivalence based on functional and cultural analogies. In Poland, the cultural turn in literary translations started with Stanisław Barańczak's publication of his influential collection of essays Ocalone w thumaczeniu [Saved in Translation] (1992). According to Barańczak, the translator's most important task is a proper interpretation of the original, revealing in the text its "semantic dominant" (dominanta semantyczna). The last notion is

\footnotetext{
${ }^{6} \mathrm{Nida}$ is rather critical of a narrow understanding of translation as an imitation of the original text. For example, he blames Arnold for his attempts to "reproduce Homer in English hexameter" Moreover, according to Nida, "Arnold was quite unwilling to accept as a criterion of a translated work that it should have essentially the same effect upon the average reader today as it had for the original receptors. As a Bible translator, Arnold was not, however, translating for people in general, but for a selected audience who knew the originals and could read the translation with their mind's eye on the Greek" (Nida 1964, 20).
} 
a structural element, which serves as the key to the overall sense of the literary work. If the translator does not manage to find and recreate the "semantic dominant," the translation fails as a work of art (Barańczak 1992, 36-37). Not only was Barańczak a translator, but he was an important poet, and his essential aestheticism resulted from his belief in the metaphysical power of the word.

A less radical form of criticism against the paradigm of the formal equivalence were cognitive-communicative theories formulated independently by Elżbieta Tabakowska and Krzysztof Hejwowski. For Tabakowska, the semantic dominant is most conspicuous in the text's imagery, consisting of several levels, such as the "scene," which can be defined as the smallest semantic unit of the literary work. The "scene" has its "scope," "setting," "figures," "participants," "level of specificity," but also "perspective," "abstract motion," and "directionality" (Tabakowska 1995, 41). A successful translation renders all those elements in such a way that the process of translation "becomes more like an individual interpretation of a musical score than a reproduction of a picture, which is one of the classical metaphors employed in translation theory" (Tabakowska 1995, 41). On the other hand, Krzysztof Hejwowski stresses the importance of efficiency in the process of communication that a successful translation should ensure. Similarly to Barańczak, he claims that the most important aspect of translation is interpretation of the original, aiming at a creation of a model of the world presented in the original (Hejwowski 2012, 166). As for the process of translation itself, it follows the pattern of a projected bi-polar reader: on the one end of the spectrum or pole, the translator imagines an expert reader, an authority in a certain area; on the other end, there is an average reader, who knows neither the language nor the culture of the original text. According to Hejwowski, the translator constantly jumps between those two heuristic perspectives and interprets the text as those two types of readers would interpret it (Hejwowski 2012, 167). Hejwowski was a literary translator himself and his translation theories resulted from his long professional practice.

In contemporary Translation Studies, literary translations are no longer pivotal for theorists and translators themselves, and in an increasingly digital reality the global economy has replaced printed books with online publications and software. Accordingly, in the context of information technology, translation gests quickly transformed into globalization, internationalization, and localization, which are forms of adaptation to the requirements of foreign markets.

The ten papers presented here try to examine the notion of equivalence from multiple perspectives, tracing its legitimacy within the discourse of Translation Studies (Lucyna Harmon); analyzing its fluctuations in translations of classical literature (Ilona Dobosiewicz, Andrzej Czaplak), or its more popular sister (Jarosław Włodarczyk); or video games, which are already more marketable than literature (Debora Onik and Piotr Maziarz); looking for it in Talmud translations into Polish (Roman Marcinkowski); or translations of the Bible (Jakub Pogonowski); or the translations of Hausa proverbs (Patryk Zając); consulting dictionaries for its presence (Monika Rychlicka); and last but not least, considering it within the context of translation didactics (Agnieszka Kałużna). What all these papers confirm univocally seems to be very simple: without equivalence, there would be no Translation Studies - and no translation. 


\section{REFERENCES}

Barańczak, Stanisław. 1992. Ocalone w tłumaczeniu. Kraków: Wydawnictwo a 5.

Bassnett, Susan, and André Lefevere. 1998. "Introduction. Where Are We in Translation Studies?". In Constructing Cultures: Essays on Literary Translation, edited by Susan Bassnett, and André Lefevere, 1-11. Clevedon: Multilingual Matters.

Genzler, Edwin. 1998. "Foreword." In Constructing Cultures: Essays on Literary Translation, edited by Susan Bassnett, and André Lefevere, ix-xxii. Clevedon: Multilingual Matters.

Hejwowski, Krzysztof. 2012. Kognitywno-komunikacyjna teoria przekładu. Warszawa: PWN.

Jarniewicz, Jerzy. 2018. Tłumacz między innymi. Szkice o przekładach, językach $i$ literaturze. Wrocław: Ossolineum.

Lee, Tong King. 2018. Applied Translation Studies. London: Palgrave.

Lefevere, André. 1999. "Composing the Other." In Post-Colonial Translation: Theory and Practice, edited by Susan Bassnett, and Harish Trivedi, 75-94. London: Routledge.

Nida, A. Eugene. 1964. Towards a Science of Translating. With Special Reference to Principles and Procedures Involved in Bible Translating. Leiden: E. J. Brill.

Tabakowska, Elżbieta. 1995. "Językoznawstwo kognitywne w teorii i praktyce

Przekładu. Oleodruk i symfonia na dwa fortepiany.” In Między oryginatem a przekładem, edited by Jadwiga-Konieczna Twardzikowa, and Urszula Kropiwiec, 31-41. Kraków: Universitas.

This work is licensed under the Creative Commons Attribution 3.0 Unported License. http://creativecommons.org/licenses/by/3.0/

AUTHOR'S BIO: Paweł Marcinkiewicz teaches at the University of Opole. His interests focus on American poetry and translation theory. He published The Rhetoric of the City: Robinson Jeffers and A.R. Ammons (2009) and "Colored Alphabets' Flutter." John Ashbery and the Twentieth Century American Avant-Gardes ( 2012).

E-MAIL: pmarcinkiewicz@uni.opole.pl 